\title{
IT'S ALL IN MARSHALL: THE IMPACT OF EXTERNAL ECONOMIES ON REGIONAL DYNAMICS
}

\author{
DAVID B. AUDRETSCH \\ OLIVER FALCK \\ STEPHAN HEBLICH
}
CESIFO WORKING PAPER NO. 2094
CATEGORY 5: FisCAl POLICY, MACROECONOMICS AND GROWTH
SEPTEMBER 2007
An electronic version of the paper may be downloaded
- from the SSRN website: Www.SSRN.com
- from the RePEc website: Www.RePEc.org
- from the CESifo website: www.CESifo-group.org/wp




\title{
IT'S ALL IN MARSHALL: THE IMPACT OF EXTERNAL ECONOMIES ON REGIONAL DYNAMICS
}

\begin{abstract}
Marshall's student Pigou noted: "It's all in Marshall.” From a static point of view, this seems rather bold in a constantly changing world. However, this statement becomes more plausible in a dynamic context, where principles are subject to change. Indeed, over time, Marshall's concept of external economies gained fresh perspective as new concepts of regional characteristics and agglomeration evolved. This paper focuses on the impact of region and industry on dynamics and growth, distinguishing between industrial districts, industrial agglomerations and urban agglomerations. Based on these three types, we use a comprehensive large dataset on German regions to test the following: (1) these regions can be characterized by given location variables describing geographic location, firm structure, and surrounding location factors and (2) every region's locational variables affects its potential for dynamics.
\end{abstract}

JEL Code: O18, R11, R12.

Keywords: regional and urban development, agglomeration, industrial districts, location factors, external economies.

David B. Audretsch

Max Planck Institute of Economics

Kahlaischestr. 10

07745 Jena

Germany

audretsch@econ.mpg.de
Oliver Falck

Ifo Institute for Economic Research

at the University of Munich

Poschingerstr. 5

81679 Munich

Germany

falck@ifo.de

\author{
Stephan Heblich \\ Max Planck Institute of Economics \\ Kahlaischestr. 10 \\ 07745 Jena \\ Germany \\ Heblich@econ.mpg.de
}

This version: August 2007 


\section{Introduction}

“It's all in Marshall!” is a phrase famously attributed to Pigou. As one of Marshall’s students, Pigou taught his students from Marshall's Principles of Economics, which he apparently regarded as being all-embracing. ${ }^{1}$ Even though Marshall's theory dominated economic thinking in Great Britain, particularly at Cambridge, until the 1930s, Lionel Robbins (1971), at that time the head of the London School of Economics (LSE), began to criticize the Cambridge school's general ignorance of developments written in languages other than the "king’s tongue.”” Or, in the language of economics, Robbins was critical of Cambridge’s neoclassic attitude, a school of thought significantly influenced by Marshall. The Cambridge scholars were stuck in a static equilibrium they supposed to be pareto-efficient-it's all in Marshall!

However, according to Schumpeter, this adherence to the static conventionalism of Marshall's Principles contradicts Marshall himself, as "he was fully aware that he was building an essentially temporary structure” (1941, p. 237). Thus, Marshall accepted the laws of evolution underlying economic development and thus regarded his work as a contemporary contribution subject to change-which is apparently in line with Schumpeter's theory. This implies that the quality and sustainability of Marshall's Principles is not determined by their static perfection but by their dynamic adaptivity. Not so long ago, Marshall's Principles experienced renewed popularity, or at least interest, when Krugman (1991) formalized Marshall’s theory on external economies and developed the “new economic geography” based on it. Prior to Krugman, Becattini (1979) had already revisited Marshall’s external economies to explain the performance of the so-called Italian industrial districts. Following these

\footnotetext{
1 “The first time one reads the Principles one is very apt to think it is all perfectly obvious. The second time one has glimpses of the fact that one does not understand it at all. ... When one discovers that one did not really know beforehand everything that Marshall has to say, one has taken the first step towards becoming an economist!” (Pigou, 1956, p. 86).
} 
pioneers, we will also deal with Marshall's ideas, but from an evolutionary perspective. As described above, we regard Marshall's ideas as still valid—when adjusted for environmental development. In our case, this concerns the increasing importance of knowledge and creativity in production.

With regard to external economies, Marshall emphasized the importance of the industrial atmosphere that enables people living in the district to learn the industry as if it was "in the air,” that is, by a sort of osmosis. In Marshall's day of mass production, learning was probably related to abilities other than those necessary in today's industrial climate, but the existence of regional agglomerations in this age of global sourcing shows that even though Marshall's ideas might have evolved over time, they certainly have not stopped being relevant. Today’s knowledge-based production simply changed the venue of knowledge osmosis, not the fact that it exists. In the contemporary economy knowledge is embodied in the ideas of people, including creativity, rather than the endowment with natural resources and manufacturers, that is critical to the creation of future rents. In this regard, Florida (2002a) argues that it is the rise of what he terms "the creative class" that fosters innovation and subsequent economic growth. Creative people are attracted to regions with tolerant and diverse populations. Lee et al. (2004) found evidence supporting Florida's theory in an empirical test based on data from the United States.

Thus, there are certain factors that determine a region's stock of knowledge, which, in turn, will eventually contribute to innovation and growth in that region. Falck and Heblich (2008) call these factors "modern location factors". However, because there are different types of regions in every country_-peripheral regions, agglomerated regions, and urban regions_-it is plausible to assume that the modern locational factors critical for growth will also differ. In fact, we believe that there are some basic endowment factors, which when accompanied by

\footnotetext{
${ }^{2}$ For a more detailed review on the differences between Cambridge and the London School of Economics during
} 
certain special factors, will define types of regions. We expect that these region-specific location factors will depend heavily on the underlying socioeconomic structure. Therefore, in Section 2, we provide a short review of theories of economic agglomeration and develop, based on Marshall's idea of industrial districts, three archetypes of regional agglomerations that differ with regard to their particular industrial organization, geographic shape, and surrounding sociological factors. Using these distinctions as a foundation, in Section 3 we analyze a comprehensive large data set for German regions to identify which factors play an important role. In Section 4, we test these location factors' impact on regional dynamics and growth. We conclude in Section 5 and draw some implications of our work.

\section{The Evolution of Regional Agglomeration Theories}

According to Marshall (1890), firms cluster around specific locations to take advantage of external economies of scale, which he separates into three types: (1) economies resulting from access to a common labor market and shared public goods, such as infrastructure or educational institutions; (2) economies from saved transportation and transaction costs due to the regional proximity of firms along the supply chain; and (3) economies from spillovers that result from industry secrets being readily discerned due to proximity. With respect to the currently especially important knowledge spillovers, Griliches (1992) describes the essence of this industrial atmosphere as "working on similar things and hence benefiting from each other's research.”

Marshall's time was during the heyday of mass production, which became even more efficient when the assembly line was introduced - the beginning the Fordism era. Against this background, internal economies of scale created by vertical integration and cost-saving process innovation were especially important. As transportation costs were high during this period, industrial agglomeration primarily occurred in areas endowed with mineral resources 
and in proximity to important suppliers, buyers, or consumers. Apparently, industrial agglomeration was mainly the result of comparative cost advantages and relevant external economies, the so-called localization economies, arose from the size of the local industry. ${ }^{3}$ In this environment, local monopoly was considered to be more efficient. However, due to a rather introversive perspective on the firm's production process, the idea of external economies did not evolve its full explanatory power immediately. Initially, external economies manifested only as intra-industry spillovers of know-how that supported overall worker's efficiency and the breaking-in of new workers. This was the more applicationoriented and efficiency-improving part of the third Marshallian factor; potential gains from competition for new knowledge and innovations - the competitive advantage-were initially neglected. This concept did not reach its apogee until markets started to become saturated with basic mass-produced consumer goods and customers started demanding more individualized products. However, as we will see, the third Marshallian factor has emerged as the most important one in today's knowledge-based economy.

This increased customer demand for individualized products led to drastic changes in production processes; standardized mass production was no longer so much of an advantage as it once had been. Smaller batch numbers were produced and thus former internal economies of scale vanished. Manufacturers vertically disaggregated their production and started relying more on suppliers instead of producing everything themselves. Flexibility, the ability to immediately adapt to market developments, and proactivism in creating future markets were the earmarks of this new era and against this background, external economies of scale now resulting from coopetition-cooperation in regional knowledge creation with simultaneous consideration of worldwide competition for innovation-experienced a renaissance that continues to this day. This development decreased the relative importance of

\footnotetext{
${ }^{3}$ Krugman (1991, p. 14ff) provides a simple model of geographic concentration based on the interaction of increasing returns, transportation costs, and demand that leads to comparative cost advantages.
} 
(physical) resource endowment and proximity of manufacturers as factors driving regional growth as they became either almost ubiquitously available or increasing irrelevant in an increasingly globalized world. At the same time, "soft" production factors, that is, those related to personal (tacit) knowledge ${ }^{4}$ and thus the third Marshallian factor, as currently understood, became more important. Hence, Becker (1975) introduced the concept of human capital. He argues that human capital results from investment in education and training, can drive growth, and thus compensates for a comparatively low availability of physical capital. Similarly, the endogenous growth theory introduced knowledge capital as a driving factor of growth (Romer, 1986, 1990). Apparently, knowledge capital is strongly related to human capital, as the process of knowledge accumulation necessitates human capital as input. A further extension was the concept of social capital. Putnam (2000) argues that "traditional factors" such as capital, labor, and knowledge are not adequate to sufficiently explain economic performance. Additionally, social network structures among actors are necessary for knowledge to diffuse and evolve its productive impact. The social network's outcome, social capital, results from relationships of trust and tolerance inherent in social networks. Trust in the reciprocity of shared knowledge increases the flow of knowledge within the social network and boosts the so-called "localized knowledge spillovers" (Feldman, 1999). In this way, social capital eventually allows for the exploitation of "secrets", that is, knowledge that becomes obtainable by way, simply of the actors knowing each other. Current researchers are "standing on shoulders" of former researchers; they derive great benefit from former accumulated knowledge. In this context, Jaffe et al. (1993) found evidence that regionally developed knowledge is most likely to boost the accumulation of further knowledge within

\footnotetext{
${ }^{4}$ The seminal work on tacit knowledge dates back to Polanyi (1966).
} 
the same region. They traced knowledge flows via patent citations, which turned out to be geographically localized. ${ }^{5}$

Apparently, regional growth in the contemporary economic context is highly dependent on the availability of tacit knowledge (which, according to Lundvall and Johnson (1994), encompasses know-how and know-who) and external economies resulting from knowledge spillovers. Thus, the regional capacity to attract and retain human capital and stimulate tacit knowledge flows is a major determinant of regional development. However, desirable regional amenities might differ among regions. For example, more peripheral areas may be considered desirable because of their characteristically strong relational ties and traditions, whereas urbanized areas achieve attractiveness due to typically higher salaries and the type of lifestyle on offer, i.e., a variety of restaurants, theaters, cinemas, and bars or clubs.

This historical development has led to a new understanding of the relative importance of Marshall's external economies and the development of different concepts of agglomeration with regard to regional characteristics (Markusen, 1996). As we are interested in the impact of regional and industrial differences on dynamics and growth, we will distinguish three archetypes of regional agglomerations: industrial districts, industrial agglomerations, and urban agglomerations. Based on the definitions of these three regional types set out below, we argue (1) that these regions can be characterized by given location variables describing geographic location, firm structure, and surrounding location factors resulting from the underlying socio-economic structures and (2) that every region's location variables affect its potential for dynamics. Applying a comprehensive large data set on Germany, we provide an empirical test for the existence of these assumed dependencies (see Section 4).

\footnotetext{
5 “[I]n principle, a citation of Patent $\mathrm{X}$ by Patent $\mathrm{Y}$ means that $\mathrm{X}$ represents a piece of previously existing knowledge upon which Y builds” (Jaffe et al., 1993).
} 


\subsection{Industrial Districts}

To the best of our knowledge, Becattini (1979) was the first to rediscover Marshall's ideas on industrial districts. He applied Marshallian agglomeration theory to shed light on the remarkable economic performance of the Italian industrial districts in the early 1970s. ${ }^{6}$ In the course of deconstructing Fordism, with its vertically integrated firm structure, productive units of large integrated firms were broken down into small and medium-sized enterprises (SMEs) (Bianchi, 1993). These former vertically integrated SMEs now buy and sell from each other and, being highly specialized in one particular phase of production, they have successfully established niche markets that large firms cannot satisfy. Although these now smaller firms are formally independent, i.e., organizationally separated, close relationships, often involving family ties, remain between the previously consolidated units and act as social glue (Becattini, 1990). According to Granovetter (1973), strong social ties contribute to the emergence of implicit social institutions that eventually prevent free-riding. They create what Putnam (2000) calls "bounding social capital," which eventually acts as district-immanent risk and as an uncertainty management system. With regard to innovation, collective R\&D projects, on the one hand, reduce each firm's risk in case of failure and, on the other hand, accelerate the innovation process, leading to quick adaptation to market developments and emerging trends. Regarding uncertainty about future conditions, informal subcontracting enables firms to react flexibly to cycles and overcapacities without transaction costs (Amin \& Thrift, 1992). In the case of bottlenecks, the workforce may switch between firms or one firm's machinery can be used in another firm's production process (Callois \& Aubert, 2007). In short, the industrial districts "exhibit frequent and intensive exchanges of personnel between customers and suppliers and cooperation among competitor firms [coopetition] to share risk, stabilize markets, and share innovation” (Markusen, 1996). Additionally, the 
districts' industrial structures are supported by an infrastructure tailored to the particular needs of the district's industry. This includes educational infrastructure as well as financial services, technical support, and trade associations. In these complementary fields, strong social ties play an important role as well, as a shared culture and history makes it easier for people to work together to solve problems. Altogether, social capital has a favorable influence throughout the entire production sphere.

All these arguments are based on Marshallian external economies from the functional division of labor. However, regardless of their positive contributions to the emergence of external economies (see Pietrobelli, 2000; Callois and Aubert, 2007), strong social ties supporting collective action can also become an obstacle in the long run. This is the case if extraeconomic elements (i.e., implicit norms based on tradition, beliefs, and culture-in other words, the social glue) affect the district's ability to adapt to long-run changes and developments, a situation that can become critically important (and dangerous to growth) if strong relational ties prevent the integration of outsiders and thus the interregional import of new knowledge. This situation will eventually impair regional knowledge production as creativity and, thus, the potential for groundbreaking innovation, also depend on the diversity of ideas (Lee et al., 2004). Best (1990) relates an industrial district's (ID) ability to adapt to changes in the absence of organizational structures (i.e., to assure a functional division of labor over time) to whether or not it is entrepreneurial: “A fully developed ID would behave like a collective entrepreneur: It would possess the capacity to redesign process and organization as well as product” (p. 206).

With regard to geographical context, we assume that the phenomenon of industrial districts is more relevant for peripheral areas where the industrial district's major characteristic - the

\footnotetext{
${ }^{6}$ In this context, Piore and Sabel (1984) base their work on the "theory of collaborative economies" while Storper (1993) uses the term "flexible specialization" to describe these Neo-Marshallian industrial districts—not just with regard to the Italian phenomenon, but internationally.
} 
strong relational ties among small businesses—is most likely to be found. Here, everyone knows everyone else to such an extent that trust and social sanctions play an important role in everyday life (Ellickson, 1991). These social structures provide small firms with stability; they make informal institutions possible and thus lead to saved transaction costs and increased flexibility. In contrast, vertical integration in the context of complex and volatile markets is rather risky and also costly (Harrigan, 1985). Against this background, small firms have an incentive to stay small and flexible instead of integrating additional production phases. As industrial districts often emerge from a formerly large and integrated company, all relevant production phases already exist and, given these stable structures, there is not much potential for new entry. However, if there is potential for firm growth it is more likely to manifest as the creation of startups by former employees than as an increase in incumbent firm size. Further, there will be rather moderate employment growth as outsiders may find it difficult to become integrated into social networks that are based on mutual trust and strong social ties that have developed over a length of time. However, if the industrial district has established a niche market and appears to be a promising industrial atmosphere, it is likely to attract highly qualified university students who return to their home region after university instead of looking for work in an urban area.

\subsection{Industrial Agglomerations}

Just like industrial districts, industrial agglomerations are dominated by one industry and thus are rather specialized. However, they have experienced a slightly different development in the process of vertical disintegration. In contrast to the industrial districts, former highly vertically integrated companies were not completely split up into small and medium-sized companies. "An assembly of craft shops [remains] under one corporate or physical roof” (Sabel, 2002, p. 110) while other parts of the production process have been disaggregated by 
outsourcing, a strategy that originated in Japan and is known as lean production. ${ }^{7}$ This assures a highly flexible, fast-reacting production system that enables the firm to deal with increasing complexity in production. In reducing vertical integration, manufacturers create an external supply chain, a process that has been made considerably easier by low transportation costs and an almost global communication infrastructure. Globalization has made it possible for manufacturers to not only find, but to use, the cheapest inputs for their businesses. However, it turns out that only the production of standardized and labor-intensive inputs has been shifted to countries with competitive labor costs; capital-intensive production tends to stay close to home. In the automobile industry, for example, it is generally true that first- and second-tier suppliers are located in direct proximity to the original equipment manufacturer (OEM). The low vertical integration in this industry necessitates close coordination between OEM and important suppliers to phase production processes and assure just-in-time and justin-sequence production. Thus, $R \& D$ cooperation is particularly important for process innovations. Further, this network is often complemented by universities as well as by various types of service providers, including commercial cleaners and warehousemen, jobs likely to be filled by low-skilled workers.

With regard to the industrial organization of industrial agglomerations, Markusen (1996) describes it as a "hub-and-spoke" structure. In an oligopolistic market, one or a number of key firms act as the hub. Smaller firms along the supply chain circle the hub like spokes. The success of the spoke firms is highly dependent on the success of the hub firm, which, in turn, may depend on an industry lifecycle or its management. In this environment, a market structure where suppliers are less dependent is more desirable as it provides stability. On the other hand, the hubs may produce agglomerative externalities that favor small and medium-

\footnotetext{
7 "Lean production is 'lean' because it uses less of everything compared to mass production-half the human effort in the factory, half the manufacturing space, half the investment in tools, half the engineering hours to develop a new product in half of the time. Also, it requires keeping far less than half the needed inventory on
} 
sized companies that are not, or at least not directly, linked to the hub company. With regard to small business employment in industrial agglomerations, Markusen (1996) remarks that “workers' loyalties are to the core firms first, then to the district and only after that to small firms. If jobs open up in hub firms, workers will often abandon smaller employers to get onto the hub firm's payroll” (p. 303). Thus, employment growth is more likely to be reflected in the employment figures of large incumbent firms. This leads to an industrial atmosphere characterized by secure employment in large firms that focus on routinized innovation. According to Baumol (2002), routinized innovation “...is not the realm of the unexpected, of the unrestricted exercise of imagination and boldness that is the essence of entrepreneurship. It is rather the domain of memoranda, rigid cost controls, and standardized procedures, which are the hallmark of trained management” (p. 36). So although an industrial agglomeration may rarely experience a fresh and invigorating breeze of creativity from new businesses, it is also largely immune from the possibly destructive winds of change. However, as creative destruction is a way of adapting to a dynamic environment, a lack of entrepreneurial spirit carries the risk of the firm becoming inflexible, which is especially dangerous in these days of globalization.

In general, it is primarily the existence of intra-industry spillovers along the supply-chain in an industrial agglomeration region that attracts additional firms and thus contributes to employment growth, eventually leading to increasing urbanization. However, cities that grow with and around an industrial agglomeration are quite different from "natural" urban agglomerations, which will be discussed next. As we understand them, industrial agglomerations are functional regions that are a bit short on tradition and common culture because the much of the population has moved to these areas for work-related reasons, that is, there is not much of an indigent population. This makes social interactions somewhat 
anonymous in industrial agglomerations and, in general, these regions are possesses of less trust and social embeddedness than are industrial districts.

\subsection{Urban Agglomerations}

Urban agglomerations are a direct opposite of the other two types of regions described above. They are not dominated by one manufacturing industry but are, instead, historically grown centers rich with cultural life and other amenities that support a certain lifestyle. According to Glaeser et al. (2001) and Florida (2002a, 2002b), such amenities include the quality of public infrastructure, e.g., good schools, transportation-related factors, and effective crime prevention; the cultural infrastructure, e.g., restaurants and theaters; the region's aesthetics and physical setting, e.g., architecture or parks; and, finally, a desirable variety of social partners and the opportunity to easily become accepted and part of the region's social network. In contrast to industrial districts, cities are not generally known for stable and strong relational ties. There are, of course, strong social ties in cities, but they do not cover the entire city-community; rather, they involve smaller parts of the city, for example, a neighborhood or a workplace. These social networks will have "weak" links to other networks, for example, a person's friendship network may include one or two of his business contacts, thus loosely linking the two networks. Eventually, this leads to diverse social networks of strong ties within the city-community that are interconnected via weak ties. Thus the city-community is somewhat heterogeneous and there are a great number of weak ties that act as gateways into social networks. On the one hand, this type of social network system leads to less stability within the city-community. However, on the other hand, it is exactly the existence of rather weak social ties, i.e., connecting factors, that facilitates the integration of outsiders and thus supports the inflow and spread of fresh knowledge and new ideas.

This creates a business environment and atmosphere that, according to Jacobs (1969), supports urbanization externalities instead of the localization economies inherent in industrial 
districts and industrial agglomerations. While the concept of localization economies implies the emergence of a local monopoly of one industry and the importance of intra-industry spillovers, the concept of urbanization externalities assumes the superiority of diversity and local competition. In this context, "it should be emphasized that by local competition, Jacobs does not mean competition within product markets ... Jacobs, rather, is referring to the competition for the new ideas embodied in economic agents [Schumpeter's entrepreneurs]" (Audretsch \& Keilbach, 2004). However, we are not concerned in this paper with the distinction between diversity and specialization; rather, we follow Duranton and Puga (2001), who argue that this difference reflects nothing but the product lifecycle's dynamics across space. In the early formative and innovative stages of the lifecycle, firms are more likely to locate in a metropolis where they can benefit from its diverse economies and creative atmosphere and corresponding inter-industry spillovers. However, "once they have 'innovated'-settled on a product line or process - they move to (district-like) locales specialized in the activities they will continue to pursue” (Sabel, 2002).

Markusen's (1996) concept of "satellite platforms" is a good description of an urban agglomeration with regard to firm structure. Following Duranton and Puga (2005), the functional specialization of different regions leads to management activities and thus multinational enterprise (MNE) headquarters being located in diversified metropolises, whereas production activities are located in smaller and/or specialized cities. ${ }^{8}$ According to this line of thought, headquarters are the locus of organizational coordination (management activities) and of the basic research that leads to technological breakthroughs and product innovations. As the products of these R\&D departments are likely to "spill” out into the air (secrets are notoriously hard to keep!), the $\mathrm{R} \& \mathrm{D}$ departments are instrumental in creating an innovative atmosphere marked by externalities in form of tacit knowledge flows that support

\footnotetext{
${ }^{8}$ Bade et al. (2003) tested this theory for Germany using data from 1976-2002 and found evidence in support of
} 
of the emergence of spinoffs and/or startups, types of enterprises that are believed to be a driving force of innovation (cf. Audretsch, 1995). Further, a metropolis's lifestyle amenities, representativeness, and international connections are directly linked to its being chosen as an MNE's headquarters. For example, MNE management travel frequently and thus prefer to have an airport conveniently nearby; a city's reputation as a flourishing center of commerce signal the company's status; a city's lifestyle and openness may make it easier for the MNE to attract top-level executives.

\section{Data Description}

Based on Marshall's three dimensions of external economies, Figure 1 presents an overview of the factors we expect to be of particular relevance in creating a certain type of industrial atmosphere. Our data are generated from the German Social Insurance Statistics (see Fritsch \& Brixy, 2004, for a description of this data source). The Social Insurance Statistics requires every employer to report information, e.g., qualifications, about every employee subject to obligatory social insurance. The information collected can be transformed into an establishment file that provides longitudinal information about the establishments and their employees. The unit of measurement is the "establishment," not the company, which is a suitable unit of measurement for regional studies. The empirical data thus derived include two categories of entities: firm headquarters and subsidiaries. As each establishment with at least one employee subject to social security has a permanent individual code number, startups and closures can be identified: the appearance of a new code number can be interpreted as a startup, the disappearance of a code number can be interpreted as a closure. New businesses with more than 20 employees in the first year of their existence are excluded. As a result, a considerable number of new subsidiaries of large firms contained in the database are not counted as startups. However, the share of new establishments in the data with more than 20 
employees in the first year is rather small (about 2.5\%). Ignoring size limits does not lead to any significant change in our results.

\section{Figure 1: Marshall's external economies in space}

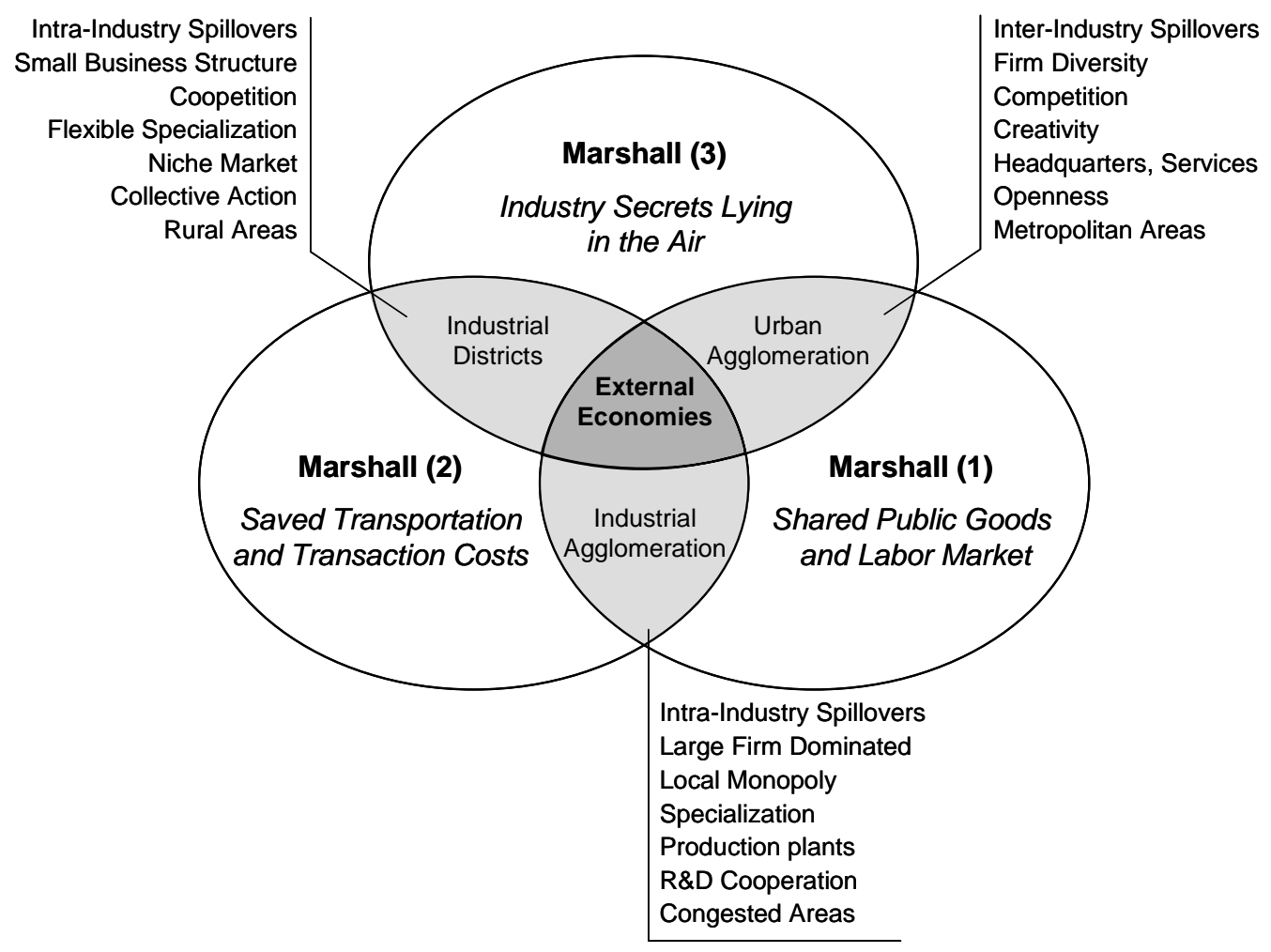

Our indicators are calculated for 75 West German planning regions as means over the period from 1987 to $2000 .^{9}$ The spatial concept of planning regions focuses on commuter distances. Planning regions consist of several districts and include at least one core city and its surroundings.

Additionally, we merge data from the German Patent Atlas and from the Federal Office for Building and Regional Planning. The German Patent Atlas provides information on the number of patents applied for in a planning region and distinguishes between three groups of applicants_-businesses, universities and research institutes, and natural persons (cf. Greif \& Schmiedl, 2002). The Federal Office for Building and Regional Planning publishes several

\footnotetext{
${ }^{9}$ We restrict the analysis to West Germany as empirical analyses have shown that economic conditions in East Germany in the 1990s were mainly driven by the transformation process to a market economy (cf. Fritsch, 2004).
} 
infrastructure indicators of the availability of modern transportation systems in a region (cf. Maretzke, 2005).

We also include indicators for the regional labor market pool and the availability of public goods, infrastructure, cultural life, and business services. We also have indicators for the industry distribution in a region. Finally, indicators that characterize the largest two-digit manufacturing industry in a region are included. Note in this context that our special focus on the German manufacturing industry is justified by its extraordinary importance, both in the past and today. We account for the size distribution and the qualification distribution of the employees in this dominant industry. Table 1 summarizes our variables and describes in more detail the method of calculation.

With regard to the regional archetypes introduced in Section 2, we are aware of the limitations associated with meso-level data, which cannot perfectly reflect the underlying socio-economic structures. However, if one wants to reach beyond the more usual case-study approach and achieve a measure of generalizability, as we do, it is necessary to draw on broader indicators that are available for a larger variety of regions. We therefore do a factor analysis to specify the regional indicators and identify the driving forces behind them. 
Table 1: Regional Indicators

\begin{tabular}{|c|c|}
\hline Variable & $\begin{array}{l}\text { Description } \\
\text { Source }\end{array}$ \\
\hline Infrastructure1 & $\begin{array}{l}\text { Reciprocal value of reachability of the nearest three national or international } \\
\text { agglomerations in combined road and rail traffic (in minutes); } 2004 \\
\text { Federal Office for Building and Regional Planning }\end{array}$ \\
\hline Infrastructure2 & $\begin{array}{l}\text { Reciprocal value of reachability of European metropolis in combined road and air } \\
\text { traffic (in minutes); } 2004 \\
\text { Federal Office for Building and Regional Planning }\end{array}$ \\
\hline Infrastructure3 & $\begin{array}{l}\text { Availability of modern transportation system (reciprocal value of reachability in } \\
\text { minutes); } 2004 \\
\text { Federal Office for Building and Regional Planning }\end{array}$ \\
\hline Share of bohemians & $\begin{array}{l}\text { Share of publicists, musicians, actors, painters, and designer over all employees } \\
\text { subject to social security; average over the timespan 1987-2000 } \\
\text { Social Insurance Statistics }\end{array}$ \\
\hline Knowledge transfer & $\begin{array}{l}\text { Share of employees in knowledge transfer institutions over all employees subject to } \\
\text { social security; average over the timespan 1987-2000 } \\
\text { Social Insurance Statistics }\end{array}$ \\
\hline Business services & $\begin{array}{l}\text { Share of employees in business services over all employees subject to social security; } \\
\text { average over the timespan 1987-2000 } \\
\text { Social Insurance Statistics }\end{array}$ \\
\hline Patents university & $\begin{array}{l}\text { Share of patents applied for by universities and research institutes; average over the } \\
\text { timespan 1995-2000 } \\
\text { German Patent Atlas }\end{array}$ \\
\hline Patents natural person & $\begin{array}{l}\text { Share of patents applied for by natural persons; average over the timespan 1995-2000 } \\
\text { German Patent Atlas }\end{array}$ \\
\hline Employees low-skilled & $\begin{array}{l}\text { Share of low-skilled employees over all employees subject to social security; average } \\
\text { over the timespan 1987-2000 } \\
\text { Social Insurance Statistics }\end{array}$ \\
\hline Employees middle-skilled & $\begin{array}{l}\text { Share of middle-skilled employees over all employees subject to social security; } \\
\text { average over the timespan 1987-2000 } \\
\text { Social Insurance Statistics }\end{array}$ \\
\hline Employees high-skilled & $\begin{array}{l}\text { Share of high-skilled employees over all employees subject to social security; average } \\
\text { over the timespan 1987-2000 } \\
\text { Social Insurance Statistics }\end{array}$ \\
\hline Engineers & $\begin{array}{l}\text { Share of engineers and natural scientists over all employees subject to social security; } \\
\text { average over the timespan 1987-2000 } \\
\text { Social Insurance Statistics }\end{array}$ \\
\hline Employees manufacturing & $\begin{array}{l}\text { Share of employees in manufacturing over all employees subject to social security; } \\
\text { average over the timespan 1987-2000 } \\
\text { Social Insurance Statistics }\end{array}$ \\
\hline Employees dominant industry & $\begin{array}{l}\text { Share of employees in dominant manufacturing industry over all employees subject to } \\
\text { social security; average over the timespan 1987-2000 } \\
\text { Social Insurance Statistics }\end{array}$ \\
\hline Distance to dominant industry & $\begin{array}{l}\text { Ratio of the share of employees in dominant manufacturing industry and the share of } \\
\text { employees in the second largest manufacturing industry; average over the timespan } \\
\text { 1987-2000 } \\
\text { Social Insurance Statistics }\end{array}$ \\
\hline $\begin{array}{l}\text { Employees small businesses } \\
\text { (dominant industry) }\end{array}$ & $\begin{array}{l}\text { Share of small business employment (businesses with at most } 50 \text { employees) in } \\
\text { dominant manufacturing industry; average over the timespan 1987-2000 } \\
\text { Social Insurance Statistics }\end{array}$ \\
\hline $\begin{array}{l}\text { Employees large business } \\
\text { (dominant industry) }\end{array}$ & $\begin{array}{l}\text { Share of large business employment (businesses with at least 1,000 employees) in } \\
\text { dominant manufacturing industry; average over the timespan 1987-2000 } \\
\text { Social Insurance Statistics }\end{array}$ \\
\hline $\begin{array}{l}\text { Employees high-skilled } \\
\text { (dominant industry) }\end{array}$ & $\begin{array}{l}\text { Share of high-skilled employees in dominant manufacturing industry; average over the } \\
\text { timespan 1987-2000 } \\
\text { Social Insurance Statistics }\end{array}$ \\
\hline $\begin{array}{l}\text { Engineers } \\
\text { (dominant industry) }\end{array}$ & $\begin{array}{l}\text { Share of engineers and natural scientists in dominant manufacturing industry; average } \\
\text { over the timespan 1987-2000 } \\
\text { Social Insurance Statistics }\end{array}$ \\
\hline
\end{tabular}




\section{Marshall's External Economies in Space and Regional Dynamics}

\subsection{Locating Marshall's External Economies in Space: Factor Analysis}

The large number of indicators provides a great deal of information-i.e. variance- - to exploit in the analysis. However, it is not appropriate to add all these indicators to a regression analysis on regional dynamics. Many of the indicators reflect only slightly different aspects, which will lead to a high degree of multicollinearity in a regression analysis. The most usual way to discover which latent variables determine the variance in the manifold set of indicators is explorative factor analysis.

The factor analysis is implemented in several steps. We first undertake a principal factor analysis (cf. Fabrigar et al., 1999) on all of the regional variables (cf. Table 1). All of these variables were standardized by calculating the mean and dividing by the standard deviation. The Kayser criterion and also the scree test on the eigenvalues of the factors suggest retaining four factors. All four factors have eigenvalues larger than 1 and in the eigenvalue graph there is a break point after the fourth factor where the curve flattens out. To clarify the data structure we have further rotated the retained factors by oblique rotation. Oblique rotationwe use the promax method—allows the factors to correlate. Because we have argued that all location factors have a common basis in Marshall's external economies, an orthogonal rotation leading to completely uncorrelated factors is inappropriate for our purpose. The results of the factor analysis after oblique rotation are summarized in Table 2. The factor loadings displayed in the table are correlations between the indicators and the factors under consideration. Tabachnick and Fidell (2001) argue that a minimum factor loading of 0.32 is a good loading of an item. Further, a cross-loading item is an item that loads at 0.32 or higher on two or more factors. In this regard, Costello and Osborne (2005) argue that cross-loading 
indicators should be dropped from the analysis. We thus drop the variables share of bohemians, knowledge transfer, business services, patents natural persons, engineers, and employees large business (dominant industry) and re-run our factor analysis. ${ }^{10}$ Again, we decide to retain four factors that are rotated by promax to get a clearer structure. The results of this second factor analysis are displayed in Table 3.

It is immediately obvious from Table 3 that there are no remaining important cross-loadings. The first factor is highly positively correlated with the three infrastructure variables, the share of patents applied for by universities, and the share of high-skilled employees, while it is negatively correlated with the share of middle-skilled employees. This factor corresponds to Marshall's dimension of the access to a common specialized labor market and shared public goods, such as infrastructure and universities, and thus we label Factor 1 Infrastructure and Specialized Labor Market. The second and third factors both reflect what Marshall describes as economies from spillovers that result from industry secrets being "in the air"-that is, possible to discover due to the prevalence of social capital. The second factor is positively correlated with the share of high-skilled employees and engineers in the dominant industry and negatively correlated with the share of small business employment in the dominant industry. The third factor is correlated with the share of employees in manufacturing and with the share of low-skilled employees. These two factors appear to be opposite sides of the same coin, where the second factor describes the knowledge production sphere and the third factor describes the physical production sphere. According to Nelson and Winter's (1982) concept of technological regimes, we label Factor 2 Technological Regime. However, due to the opposite influences from R\&D-related large business employment and small business

\footnotetext{
${ }^{10}$ Note in this regard that dropping some of the variables is meaningful in itself. For example, the cross-loading of the variable share of bohemians may be due in part to the history of Germany during which the system of mini-states induced a high density of cultural facilities like theaters. Today, this situation becomes obvious when one looks at the rather evenly distributed share of bohemians and thus a lack of regional variation. For a similar reason we drop the variable business services, which contains the banking sector. The tripartite German banking system consists of private, mutual, and public banks that guarantee a more or less even distribution of banks across all regions. Accordingly, this variable does not contain much variation, either.
} 
employment in the dominant industry, the interpretation is not straightforward but ambivalent. Nelson and Winter classify industries in which innovations mostly stem from big businesses with large specialized research laboratories as routinzed regimes. In contrast, entrepreneurial regimes characterize industries where important innovations are introduced by startups and small businesses. Thus, high values of Factor 2 indicate a large and R\&D-intensive business environment characterized by the routinization of innovations, whereas smaller values of Factor 2 indicate a small business environment marked by small business networks rich in social capital. Factor 3 represents the opposite of knowledge-based production and is labeled Blue-Collar Production. Finally, Factor 4 correlates highly with our concentration measures - the share of employment in the dominant manufacturing industry and the distance of the second largest manufacturing industry from the dominant manufacturing industry-and therefore represents Marshall's idea of economies from saved transportation and transaction costs due to the regional proximity of firms along the supply chain. We label Factor 4

\section{Concentration.}

Returning to the discussion of industrial districts, industrial agglomeration, and urban agglomeration, we assume that Factor 1 is especially pronounced in urban agglomerations, less pronounced in industrial agglomerations, and small in industrial districts. Factor 2 should have an especially high value in urban agglomerations that are home to important research laboratories for the dominant industry's large businesses. A small business structure in the dominant industry, which is characteristic of industrial districts, leads to a small score for Factor 2. Blue-collar production and, therefore, a high value of Factor 3 should be pronounced in industrial agglomerations and also industrial districts. The highest value of Factor 4 and, therefore, a high degree of industry concentration should also be found in industrial agglomerations. 
Table 2: Results of factor analysis after oblique rotation

\begin{tabular}{|c|c|c|c|c|}
\hline Variable & Factor 1 & Factor 2 & Factor 3 & Factor 4 \\
\hline Infrastructure1 & 0.80 & -0.08 & 0.02 & -0.03 \\
\hline Infrastructure2 & 0.76 & 0.14 & -0.18 & -0.10 \\
\hline Infrastructure3 & 0.74 & -0.15 & 0.32 & 0.08 \\
\hline Share of bohemians & 0.56 & 0.20 & 0.42 & -0.12 \\
\hline Knowledge transfer & 0.30 & 0.34 & 0.51 & -0.10 \\
\hline Business services & 0.58 & 0.10 & 0.55 & 0.07 \\
\hline Patents university & 0.53 & -0.20 & 0.11 & 0.12 \\
\hline Patents natural person & -0.34 & -0.33 & 0.56 & -0.06 \\
\hline Employees low-skilled & -0.03 & -0.10 & -0.90 & -0.08 \\
\hline Employees middle-skilled & -0.78 & 0.17 & 0.28 & 0.04 \\
\hline Employees high-skilled & 0.72 & 0.29 & 0.19 & 0.01 \\
\hline Engineers & 0.63 & 0.36 & -0.02 & 0.13 \\
\hline Employees manufacturing & -0.02 & 0.09 & -0.90 & 0.05 \\
\hline Employees dominant industry & 0.02 & -0.02 & -0.26 & 0.85 \\
\hline Distance to dominant industry & -0.02 & -0.12 & 0.19 & 0.95 \\
\hline $\begin{array}{l}\text { Employees small businesses } \\
\text { (dominant industry) }\end{array}$ & 0.10 & -0.76 & 0.16 & -0.17 \\
\hline $\begin{array}{l}\text { Employees large business } \\
\text { (dominant industry) }\end{array}$ & -0.03 & 0.56 & 0.04 & 0.43 \\
\hline $\begin{array}{l}\text { Employees high-skilled } \\
\text { (dominant industry) }\end{array}$ & 0.08 & 0.92 & 0.07 & -0.15 \\
\hline $\begin{array}{l}\text { Engineers } \\
\text { (dominant industry) }\end{array}$ & 0.08 & 0.89 & 0.09 & -0.11 \\
\hline Eigenvalue & 6.09 & 4.67 & 3.95 & 2.40 \\
\hline Proportion of variance & 0.40 & 0.30 & 0.26 & 0.16 \\
\hline
\end{tabular}

Important cross-loadings are high-lighted.

Table 3: Results of factor analysis after elimination of cross-loadings and oblique rotation

\begin{tabular}{|c|c|c|c|c|}
\hline Variable & Factor 1 & Factor 2 & Factor 3 & Factor 4 \\
\hline Infrastructure1 & 0.75 & -0.02 & -0.08 & -0.04 \\
\hline Infrastructure2 & 0.74 & 0.19 & 0.16 & -0.09 \\
\hline Infrastructure3 & 0.73 & -0.05 & -0.31 & 0.07 \\
\hline Patents university & 0.50 & -0.12 & -0.14 & 0.11 \\
\hline Employees low-skilled & 0.01 & -0.14 & 0.91 & -0.05 \\
\hline Employees middle-skilled & -0.76 & 0.07 & -0.31 & 0.01 \\
\hline Employees high-skilled & 0.62 & 0.32 & -0.19 & 0.02 \\
\hline Employees manufacturing & -0.03 & 0.04 & 0.85 & 0.10 \\
\hline Employees dominant industry & 0.01 & 0.00 & 0.27 & 0.84 \\
\hline Distance to dominant industry & -0.03 & -0.07 & -0.17 & 0.94 \\
\hline $\begin{array}{l}\text { Employees small businesses } \\
\text { (dominant industry) }\end{array}$ & 0.03 & -0.63 & -0.17 & -0.19 \\
\hline $\begin{array}{l}\text { Employees high-skilled } \\
\text { (dominant industry) }\end{array}$ & 0.05 & 0.96 & -0.05 & -0.07 \\
\hline $\begin{array}{l}\text { Engineers } \\
\text { (dominant industry) }\end{array}$ & 0.04 & 0.93 & -0.08 & -0.03 \\
\hline Eigenvalue & 3.60 & 3.03 & 2.42 & 1.86 \\
\hline Proportion of variance & 0.38 & 0.32 & 0.26 & 0.20 \\
\hline Label & $\begin{array}{l}\text { Infrastructure } \\
\text { and specialized } \\
\text { labor market }\end{array}$ & $\begin{array}{l}\text { Technological } \\
\text { regime }\end{array}$ & $\begin{array}{l}\text { Blue-collar } \\
\text { production }\end{array}$ & Concentration \\
\hline
\end{tabular}

Loadings characterizing factors are highlighted. 
Based on these four factors, we categorize West German planning regions by means of a hierarchical average linkage cluster analysis with Euclidean dissimilarity measure. Figure 2 shows the dendrogram for the cluster analysis, where we identify six different groups. Table 4 presents the corresponding descriptive statistics of the four factors by group. Regarding the three regional archetypes introduced in Section 2, Group 3 is made up of industrial districts with a small value for Factor 2 and the highest value for Factor 3, indicating a productionoriented small business environment in which 12 out of 23 regions are dominated by the automotive or electric industry. Group 3 is further defined by a rather low score for Factor 1 (Infrastructure and Specialized Labor Market) and an above average concentration (Factor 4). Group 5 represents industrial agglomeration, with a high value for Factor 3 and an especially high value for Factor 4. Finally, Group 6 is what we describe as urban agglomerations with pronounced values of Factors 1 and 2. Figure 3 is a graphic presentation of our groups. The prototype of an urban agglomeration is the metropolitan area of Munich. Industrial agglomerations are found in those parts of Germany where large production plantsespecially those connected to automotive production-contributed to the development of regions around cities such as Ingolstadt (Audi production facility), Landshut (BMW production facility), and Wolfsburg (Volkswagen production facility). Finally, industrial districts are located in rather peripheral areas characterized by small businesses. Clearly visible is the metal processing industrial district south of Stuttgart, which was subject to analyses by Piore and Sabel (1984), Cooke (1996), and Porter (1990). 
Figure 2: Dendrogram for the hierarchical cluster analysis

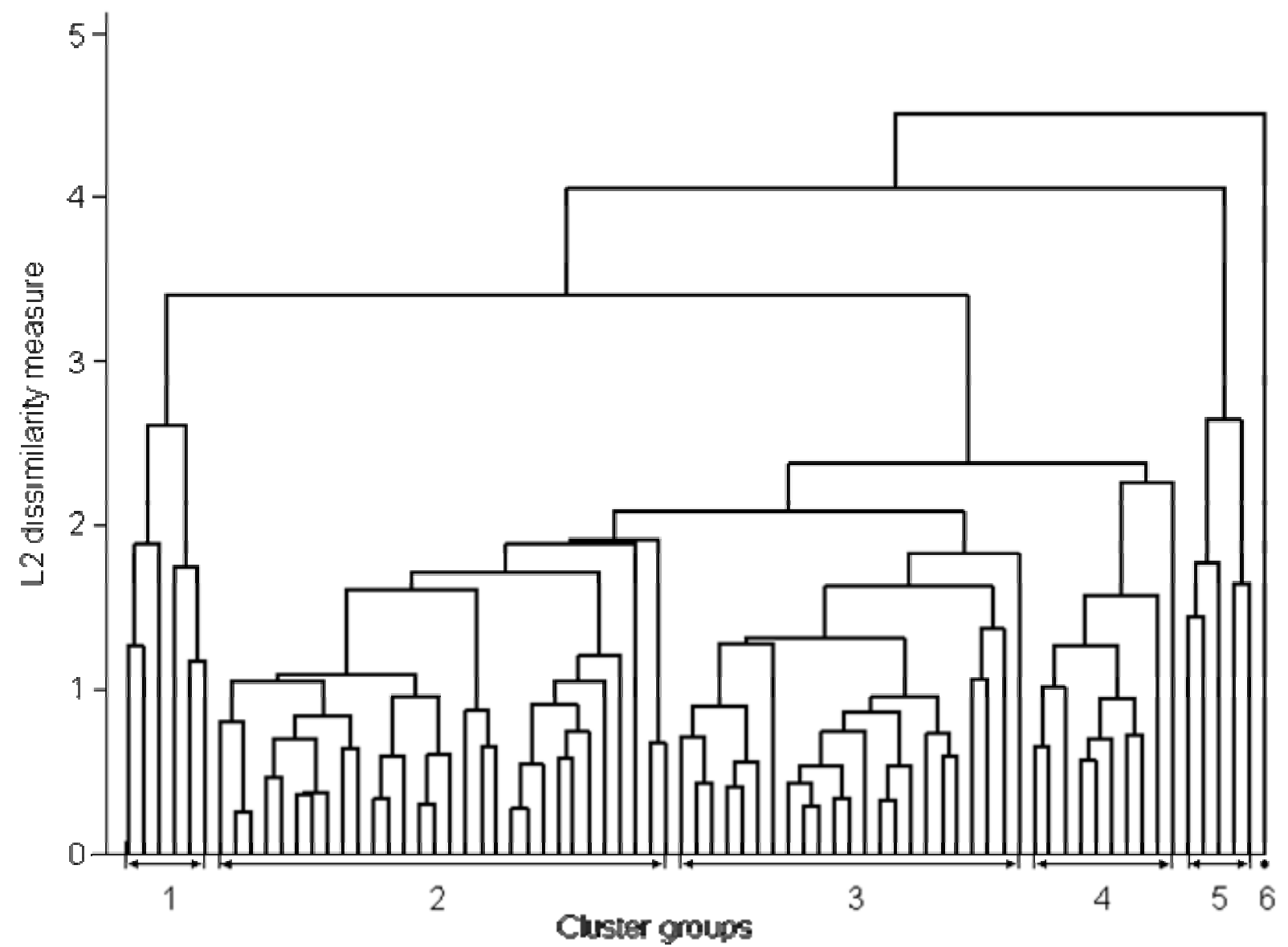

Archetypes: Group 3: Industrial District (IA); Group 5: Industrial Agglomeration (IA); Group 6: Urban Agglomeration (UA)

Others: Group 1: Tendency towards UA; Group 2: Rest; Group 4: Between IA and UA

Among the remaining three groups, two have elements of the three regional archetypes, but because one factor is missing, cannot be classified into any of the three archetype groups. Group 1 is close to being an urban agglomeration and thus we label it Tendency to UA. It features an excellent infrastructure and specialized labor market (Factor 1), is marked by diversity (low Factor 4), and shows the lowest value of Factor 3. However, the region lacks a high score for Factor 2-our indicator for the R\&D-intensive and creative part of today's industrial production. Looking at our map (Figure 3) sheds some light on this situation. It turns out that, among others, the regions around Frankfurt and Hamburg belong to Group 1. While Frankfurt is the site of Germany's banking sector, Hamburg is home to the media industry, including large publishing houses and the advertising industry. Apparently, the service sector predominates in both regions and thus they might have been glossed over due 
to our concept's focus on the manufacturing sector. In contrast, the interpretation of Group 4 is straightforward. We label this group Between IA and UA as it shows typical characteristics of an industrial agglomeration, i.e., relatively high scores for Factors 1 and 3 and, the same time, clearly less concentration (Factor 4) than the archetype industrial agglomeration. This group has a high Factor 2 value, a sign that it is an urban agglomeration, which is supported by the fact that four out of ten regions in this group are dominated by the chemical industry, well known to depend heavily on R\&D laboratories. Finally, Group 2 does not feature any specifics that might support industrial agglomeration. Group 2 regions have the lowest scores for Factors 1, 2, and 4 and a relatively low score for Factor 3. Thus, these regions are characterized by a diversified small business environment that cannot solely be attributed to production. Generally, these characteristics might hold for rural areas that are dominated by agriculture and/or tourism. The location of these regions, as well as the fact that 12 out of 23 are dominated by food production, would support this assumption (see Figure 4), but as we cannot explicitly distinguish these sectors, we prefer to label this regions Rest.

Table 4: Descriptive Statistics

\begin{tabular}{lccccccccc}
\hline & \multicolumn{2}{c}{ Factor 1 } & \multicolumn{2}{c}{ Factor 2 } & \multicolumn{2}{c}{ Factor 3 } & \multicolumn{2}{c}{ Factor 4} \\
& Mean & Std.Dev. & Mean & Std.Dev. & Mean & Std.Dev. & Mean & Std.Dev. \\
\hline Group 1 (6 obs.) & 2.17 & 0.55 & 0.33 & 1.21 & -1.36 & 0.80 & -0.30 & 0.55 \\
Group 2 (30 obs.) & -0.48 & 0.56 & -0.50 & 0.70 & -0.58 & 0.45 & -0.31 & 0.47 \\
Group3 (ID, 23 obs.) & -0.32 & 0.46 & -0.19 & 0.54 & 1.01 & 0.49 & -0.13 & 0.39 \\
Group 4 (10 obs.) & 0.75 & 0.68 & 1.02 & 0.58 & -0.06 & 0.40 & -0.11 & 0.40 \\
Group 5 (IA, 5 obs.) & -0.00 & 0.55 & 0.68 & 1.03 & 0.81 & 0.77 & 3.06 & 0.85 \\
Group 6 (UA, 1 obs.) & 1.48 &. & 3.76 &. & -0.94 &. & -0.15 &. \\
\hline Overall (75 obs.) & 0.00 & 1.00 & 0.00 & 1.00 & 0.00 & 1.00 & 0.00 & 1.00 \\
\hline
\end{tabular}


Figure 3: Spatial distribution of regional agglomerations

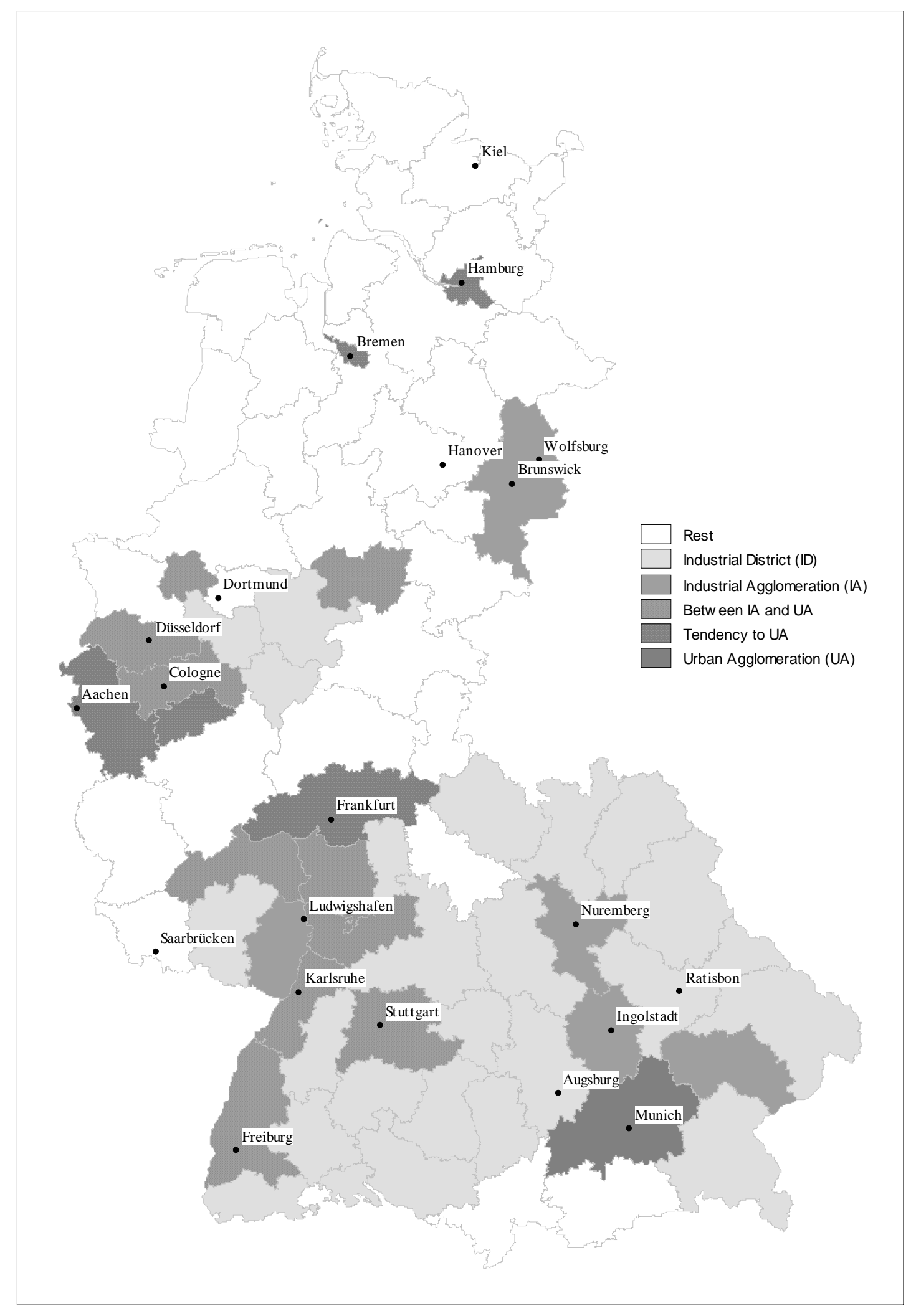




\subsection{Linking Marshall's External Economies to Regional Dynamics}

To arrive at an understanding of the relationship between the four factors previously extracted and regional dynamics, we perform multivariate regression analysis. We define dynamics as regional entry rates and employment growth. Entry rates are calculated as the number of startups in manufacturing and services per 1,000 employees in the region where we calculate means of the yearly entry rates over the period from 2000 to 2004. The employment growth rates are also calculated as means of yearly employment growth in the period from 2000 to 2004. These data are derived from the German Social Insurance Statistics and the corresponding establishment file. From Table 5, one can easily see that urban agglomerations, industrial agglomerations, and industrial districts are the best performing regions with regard to employment growth. However, overall employment growth is negative in most regions, apparently due to the recession that occurred during the period under study, 2000 to 2004 . Further, there is a decrease in low-skilled employment and an increase in high-skilled employment in all regions, a shift that indicates a Germany-wide trend. Sinn (2007) argues that the German all-embracing welfare state has distorted the German wage structure to such a degree that wages for low-skilled workers and even for middle-skilled employees are no longer competitive in today's globalized world, and that this has caused increased unemployment for the low- and middle-skilled workforce. As suspected, net entry rates are rather small in industrial districts and industrial agglomerations, while they are above average in urban agglomerations. 
Table 5: Performance of groups

\begin{tabular}{|c|c|c|c|c|c|c|c|c|c|c|}
\hline & \multicolumn{2}{|c|}{$\begin{array}{l}\text { Entry Rate (per } \\
\text { 1,000 employees) }\end{array}$} & \multicolumn{2}{|c|}{$\begin{array}{l}\text { Employment } \\
\text { Growth (\%) }\end{array}$} & \multicolumn{2}{|c|}{$\begin{array}{l}\text { Low-skilled } \\
\text { Employment Growth } \\
\text { (\%) }\end{array}$} & \multicolumn{2}{|c|}{$\begin{array}{l}\text { Middle-skilled } \\
\text { Employment Growth }\end{array}$} & \multicolumn{2}{|c|}{$\begin{array}{c}\text { High-skilled } \\
\text { Employment Growth }\end{array}$} \\
\hline & Mean & Std.Dev. & Mean & Std.Dev. & Mean & Std.Dev. & Mean & Std.Dev. & Mean & Std.Dev. \\
\hline Group 1 & 8.75 & 2.71 & -0.39 & 0.60 & -3.57 & 0.84 & -1.51 & 0.54 & 1.82 & 0.97 \\
\hline Group 2 & 8.52 & 1.56 & -0.41 & 0.49 & -3.41 & 0.87 & -1.01 & 0.50 & 2.27 & 1.05 \\
\hline Group3 (ID) & 6.64 & 1.07 & -0.24 & 0.59 & -2.91 & 0.83 & -0.43 & 0.67 & 2.38 & 0.87 \\
\hline Group 4 & 7.38 & 1.11 & -0.26 & 0.73 & -3.10 & 1.27 & -1.04 & 0.75 & 2.56 & 0.66 \\
\hline Group 5 (IA) & 6.19 & 0.74 & 0.36 & 0.69 & -2.88 & 0.78 & 0.18 & 1.12 & 3.36 & 1.94 \\
\hline Group 6 (UA) & 7.92 & . & 0.72 & . & -2.36 & . & -0.52 & . & 3.29 & . \\
\hline Overall & 7.65 & 1.69 & -0.27 & 0.60 & -3.18 & 0.92 & -0.79 & 0.75 & 2.39 & 1.04 \\
\hline
\end{tabular}


Entry rates and employment growth rates enter the regressions as dependent variables; the four factors derived in Section 4.1 enter as independent variables. As we assume that regional dynamics measured in different terms are closely intertwined, seemingly unrelated regressions (SUR) would be appropriate. However, it is well-known that in a system of seemingly unrelated regression equations with identical regressors, equation by equation OLS yields efficient estimates of the coefficient vectors (Greene, 2002, 344). We therefore perform equation by equation OLS regressions with corrected (robust) standard errors.

There could be some nonlinearities in the relationships between the four factors and the indicators for regional dynamics. Consequently, the factors also enter squared in the regression analyses. We also added interactions between the four factors. However, these factors proved insignificant in all tested specifications. Even though oblique rotation of the factors allows for correlation of the factors, we still put all factors into the regressions simultaneously in an effort to find the dominant factors driving regional dynamics. Table 6 displays the factors' correlation matrix. There is a relatively high correlation between Factor 1 and Factor 2 and somewhat moderate correlations between Factor 1 and Factor 3, between Factor 2 and Factor 4, and between Factor 3 and Factor 4.

Table 6: Factor Correlation Matrix

\begin{tabular}{lcccc}
\hline & Factor 1 & Factor 2 & Factor 3 & Factor 4 \\
\hline Factor 1 & 1.00 & & & \\
Factor 2 & 0.40 & 1.00 & & \\
Factor 3 & -0.29 & -0.09 & 1.00 & 1.00 \\
Factor 4 & -0.01 & 0.19 & 0.25 & Concentration \\
\hline \multirow{2}{*}{ Label } & Infrastructure and & Technological & Blue-collar & production \\
& specialized labor & regime & & \\
\hline
\end{tabular}

In order to avoid a possible simultaneity bias in our estimates, all indicators that entered the factor analysis were calculated on the basis of a time period from 1987 to 2000 for the data from the Social Insurance Statistics and on the basis of a time period from 1995 to 2000 for data from the German Patent Atlas. Entry rates and employment growth rates were calculated 
for the time period, 2000-2004. Only our infrastructure indicators stem from the year 2004; however, these variables can be assumed to change very slowly over time.

Table 7 displays the regression results. They clearly demonstrate that the factors driving regional employment growth are generally different from those driving regional firm entry. Factor 3 is significant for entry rate and employment growth, but affects them in different directions, which indicates a tradeoff. In contrast, Factor 1 and Factor 2 apply to firm entry only, while Factor 4 solely affects employment growth, and does so significantly (see Table 7). Table 8 displays the marginal effects (with their standard errors) of the factors at each group mean. These results show a more detailed picture, including our six groups of regions. The results suggest that Factor 1 has a significantly negative marginal effect on entry rates in industrial agglomerations and industrial districts, while this effect is significantly positive in urban agglomerations. Obviously, this reflects differences in each region's business environment and the corresponding ways the creativity of the region's skilled labor force is channeled. As hypothesized in Section 2, entries in urban agglomerations are more likely to be spinoffs by employees who previously worked in an incumbent's R\&D department and thus are knowledge intensive and "high-tech." ${ }^{\prime 1}$ In contrast, loyalty to incumbent firms and workplace satisfaction reduce the likelihood of a startup by the regional skilled workforce. Factor 2 has a significantly negative marginal effect on entry rates in industrial districts. This seems plausible, as Factor 2 indicates that an R\&D-oriented large business environment that is more likely to create high-tech spinoffs at the technological edge than startups in traditional fields or niche markets. The marginal effect on net entry of Factor 3 is significantly negative for all groups; in contrast, an increase of Factor 3 is supportive of

\footnotetext{
${ }^{11}$ Acs et al. (2004) present a growth model considering new firm formation that diminishes the knowledge filter between the creation and exploitation of knowledge. Research and development generates new knowledge, which may then be exploited either by its developer or by another firm. When the actual developer of the new knowledge does not exploit it, and there are many reasons why he or she might not wish to do so, the knowledge can still "spill over." One of the most obvious ways knowledge spillover can happen is when a person who previously worked for the incumbent firm becomes the founder of a new firm that commercializes the unexploited knowledge.
} 
low-skilled and middle-skilled employment growth in all groups. This reflects a tradeoff as good job opportunities in manufacturing crowd out entrepreneurial spirit. This result is in line with a simple economic model of self-employment in which the nascent entrepreneur will start his or her own business only if the expected profit from that business will be higher than the wage earned in dependent employment. Furthermore, the overall positive effect of Factor 3 on employment growth can be related to Germany’s long-lasting and continuing tradition of market leadership in the manufacturing sector. Finally, an increase in industry concentration (Factor 4) has a significantly negative marginal effect on middle-skilled employment growth in all regions except industrial agglomerations. In industrial agglomerations, an increase in industry concentration is supportive of both middle-skilled and high-skilled employment growth. Here, an increase in concentration refers to additional suppliers that decide to settle near to the original equipment manufacturer and thereby create jobs for engineers as well as for skilled workers. Applying the hub-and-spoke structure image we introduced in Section 2.2., a higher density of spokes stabilizes the industry structure such that it becomes an increasingly sustainable driving wheel for regional employment growth. 
Table 7: OLS regressions with robust standard errors

\begin{tabular}{|c|c|c|c|c|}
\hline & $\begin{array}{c}\text { Entry Rate (per } \\
\text { 1,000 employees) } \\
\text { Coefficient } \\
\text { ( standard error) }\end{array}$ & $\begin{array}{c}\text { Low-skilled } \\
\text { Employment Growth } \\
(\%) \\
\text { Coefficient } \\
\text { (standard error) }\end{array}$ & $\begin{array}{c}\text { Middle-skilled } \\
\text { Employment Growth } \\
(\%) \\
\text { Coefficient } \\
\text { (standard error) }\end{array}$ & $\begin{array}{c}\text { High-skilled } \\
\text { Employment Growth } \\
(\%) \\
\text { Coefficient } \\
\text { (standard error) }\end{array}$ \\
\hline Factor 1 & $\begin{array}{l}-0.40^{*} \\
(0.21)\end{array}$ & $\begin{array}{c}0.07 \\
(0.14)\end{array}$ & $\begin{array}{l}-0.11 \\
(0.09)\end{array}$ & $\begin{array}{l}-0.17 \\
(0.15)\end{array}$ \\
\hline Squared Factor 1 & $\begin{array}{l}0.38 * * \\
(0.15)\end{array}$ & $\begin{array}{l}-0.07 \\
(0.09)\end{array}$ & $\begin{array}{l}-0.01 \\
(0.06)\end{array}$ & $\begin{array}{c}0.09 \\
(0.10)\end{array}$ \\
\hline Factor 2 & $\begin{array}{l}-0.32^{*} \\
(0.19)\end{array}$ & $\begin{array}{c}0.17 \\
(0.12)\end{array}$ & $\begin{array}{c}0.10 \\
(0.09)\end{array}$ & $\begin{array}{c}0.14 \\
(0.13)\end{array}$ \\
\hline Sqaured Factor 2 & $\begin{array}{c}0.08 \\
(0.09)\end{array}$ & $\begin{array}{c}0.04 \\
(0.06)\end{array}$ & $\begin{array}{c}0.02 \\
(0.04)\end{array}$ & $\begin{array}{c}0.02 \\
(0.07)\end{array}$ \\
\hline Factor 3 & $\begin{array}{c}-0.78 * * * \\
(0.19)\end{array}$ & $\begin{array}{c}0.41 * * * \\
(0.12)\end{array}$ & $\begin{array}{c}0.42 * * * \\
(0.08)\end{array}$ & $\begin{array}{c}0.29 * * \\
(0.14)\end{array}$ \\
\hline Squared Factor 3 & $\begin{array}{l}-0.01 \\
(0.14)\end{array}$ & $\begin{array}{l}-0.05 \\
(0.09)\end{array}$ & $\begin{array}{c}0.01 \\
(0.06)\end{array}$ & $\begin{array}{c}-0.22^{* *} \\
(0.10)\end{array}$ \\
\hline Factor 4 & $\begin{array}{l}-0.39 \\
(0.32)\end{array}$ & $\begin{array}{l}-0.33 \\
(0.21)\end{array}$ & $\begin{array}{l}-0.22 \\
(0.14)\end{array}$ & $\begin{array}{l}-0.29 \\
(0.23)\end{array}$ \\
\hline Sqaured Factor 4 & $\begin{array}{c}0.06 \\
(0.10) \\
\end{array}$ & $\begin{array}{c}0.08 \\
(0.07)\end{array}$ & $\begin{array}{c}0.13^{* * *} \\
(0.04)\end{array}$ & $\begin{array}{c}0.21 * * * \\
(0.07)\end{array}$ \\
\hline $\mathrm{N}$ & 75 & 75 & 75 & 75 \\
\hline $\mathrm{F}$ & $62.55^{* * *}$ & $21.75^{* * *}$ & $60.26^{* * *}$ & $28.12 * * *$ \\
\hline $\mathrm{R}^{2}$ & 0.45 & 0.22 & 0.44 & 0.27 \\
\hline RMSE & 1.24 & 0.80 & 0.55 & 0.88 \\
\hline
\end{tabular}

*** significant at the $1 \%$ level; ** significant at the $5 \%$ level; * significant at the $10 \%$ level 
Table 8: Marginal effects at the mean of each group

\begin{tabular}{|c|c|c|c|c|c|c|c|c|}
\hline & \multicolumn{2}{|c|}{$\begin{array}{c}\text { Entry Rate (per 1,000 } \\
\text { employees) }\end{array}$} & \multicolumn{2}{|c|}{$\begin{array}{c}\text { Low-skilled } \\
\text { Employment Growth } \\
(\%)\end{array}$} & \multicolumn{2}{|c|}{$\begin{array}{c}\text { Middle-skilled } \\
\text { Employment Growth } \\
(\%)\end{array}$} & \multicolumn{2}{|c|}{$\begin{array}{c}\text { High-skilled } \\
\text { Employment Growth } \\
(\%)\end{array}$} \\
\hline & $\begin{array}{c}\text { Marginal } \\
\text { Effect }\end{array}$ & $\begin{array}{l}\text { Standard } \\
\text { Error }\end{array}$ & $\begin{array}{l}\text { Marginal } \\
\text { Effect }\end{array}$ & $\begin{array}{l}\text { Standard } \\
\text { Error }\end{array}$ & $\begin{array}{l}\text { Marginal } \\
\text { Effect }\end{array}$ & $\begin{array}{l}\text { Standard } \\
\text { Error }\end{array}$ & $\begin{array}{l}\text { Marginal } \\
\text { Effect }\end{array}$ & $\begin{array}{l}\text { Standard } \\
\text { Error }\end{array}$ \\
\hline \multicolumn{9}{|l|}{ Factor 1} \\
\hline Group 1 & $1.25 * *$ & 0.57 & -0.23 & 0.33 & -0.15 & 0.22 & 0.22 & 0.36 \\
\hline Group 2 & $-0.76^{* *}$ & 0.31 & 0.14 & 0.20 & -0.10 & 0.13 & -0.26 & 0.22 \\
\hline Group 3 (ID) & $-0.64 * *$ & 0.27 & 0.11 & 0.18 & -0.10 & 0.12 & -0.23 & 0.20 \\
\hline Group 4 & 0.17 & 0.21 & -0.04 & 0.13 & -0.13 & 0.08 & -0.04 & 0.13 \\
\hline Group 5 (IA) & $-0.40 *$ & 0.21 & 0.07 & 0.14 & -0.11 & 0.09 & -0.17 & 0.15 \\
\hline $\begin{array}{l}\text { Group } 6 \\
\text { (UA) }\end{array}$ & $0.72 *$ & 0.37 & -0.14 & 0.22 & -0.14 & 0.15 & 0.10 & 0.24 \\
\hline \multicolumn{9}{|l|}{ Factor 2} \\
\hline Group 1 & $-0.27 *$ & 0.16 & $0.20 *$ & 0.10 & 0.11 & 0.08 & 0.15 & 0.11 \\
\hline Group 2 & -0.40 & 0.25 & 0.13 & 0.16 & 0.08 & 0.12 & 0.12 & 0.18 \\
\hline Group 3 (ID) & $-0.35^{*}$ & 0.21 & 0.15 & 0.13 & 0.09 & 0.10 & 0.13 & 0.15 \\
\hline Group 4 & -0.16 & 0.17 & $0.25 * *$ & 0.11 & $0.14^{*}$ & 0.08 & 0.18 & 0.13 \\
\hline Group 5 (IA) & -0.21 & 0.15 & $0.22 * *$ & 0.10 & $0.13 *$ & 0.07 & 0.17 & 0.11 \\
\hline $\begin{array}{l}\text { Group } 6 \\
\text { (UA) }\end{array}$ & 0.28 & 0.59 & 0.47 & 0.40 & 0.25 & 0.26 & 0.29 & 0.47 \\
\hline \multicolumn{9}{|l|}{ Factor 3} \\
\hline Group 1 & -0.75 & 0.47 & $0.55^{*}$ & 0.30 & $0.39 * *$ & 0.20 & $0.89 * *$ & 0.34 \\
\hline Group 2 & $-0.77 * * *$ & 0.28 & $0.47 * *$ & 0.18 & $0.41 * * *$ & 0.12 & $0.55^{* *}$ & 0.21 \\
\hline Group 3 (ID) & $-0.80 * * *$ & 0.29 & $0.31 *$ & 0.19 & $0.44 * * *$ & 0.12 & -0.15 & 0.21 \\
\hline Group 4 & $-0.78 * * *$ & 0.20 & $0.42 * * *$ & 0.12 & $0.42 * * *$ & 0.08 & $0.32 * *$ & 0.14 \\
\hline Group 5 (IA) & $-0.80 * * *$ & 0.25 & $0.33^{* *}$ & 0.16 & $0.44 * * *$ & 0.10 & -0.07 & 0.18 \\
\hline $\begin{array}{l}\text { Group } 6 \\
\text { (UA) }\end{array}$ & $-0.76 * *$ & 0.37 & $0.50 * *$ & 0.23 & $0.40 * *$ & 0.16 & $0.70 * *$ & 0.26 \\
\hline \multicolumn{9}{|l|}{ Factor 4} \\
\hline Group 1 & -0.43 & 0.38 & -0.38 & 0.25 & $-0.30 *$ & 0.17 & -0.42 & 0.27 \\
\hline Group 2 & -0.43 & 0.38 & -0.38 & 0.25 & $-0.30 *$ & 0.17 & -0.42 & 0.27 \\
\hline Group 3 (ID) & -0.41 & 0.34 & -0.35 & 0.23 & $-0.25^{*}$ & 0.15 & -0.34 & 0.25 \\
\hline Group 4 & -0.40 & 0.34 & -0.35 & 0.22 & $-0.25^{*}$ & 0.15 & -0.34 & 0.24 \\
\hline Group 5 (IA) & -0.02 & 0.35 & 0.16 & 0.28 & $0.58 * * *$ & 0.08 & $1.00 * * *$ & 0.23 \\
\hline $\begin{array}{l}\text { Group } 6 \\
\text { (UA) }\end{array}$ & -0.41 & 0.35 & -0.35 & 0.23 & $-0.26^{*}$ & 0.15 & -0.35 & 0.25 \\
\hline
\end{tabular}

The marginal effect of Factor $i$ at at the mean $m_{i g}$ of group $g$ is $\beta_{1 i}+\beta_{2 i} 2 m_{i g}$ with $\beta_{1 i}$ the regression coefficient of factor $i$ and $\beta_{2 i}$ the regression coefficient of the squared factor $i$. The corresponding standard error of this marginal effect is $\sqrt{\operatorname{var} \beta_{1 i}+4 m_{i g}^{2} \operatorname{var} \beta_{2 i}+2 \operatorname{cov} \beta_{1 i} \beta_{2 i} 2 m_{i g}}$.

*** significant at the $1 \%$ level; ** significant at the $5 \%$ level; * significant at the $10 \%$ level 


\section{Summary and Conclusion}

Our empirical analyses have shown that there are indeed different types of regions characterized by different mixtures of location factors that determine a region's industrial atmosphere. More peripheral areas with low accessibility indicators tend to be host to industrial districts, which are characterized by small and flexible businesses that rely on highly skilled workers. This type of business often specializes in a niche market where constant innovation is necessary. Here, startups are mainly the result of organizational consideration. In industrial agglomerations, the entrepreneurial spirit is crowded out by good wage opportunities in large and growing specialized production plants, which have emerged in the post-R\&D phase of a product lifecycle when production efficiency becomes more important to success than new ideas. Urban agglomerates are most often home to $R \& D$ departments and company headquarters. These regions offer the diversity of knowledge and creativity necessary to arrive at and commercialize ideas. Innovation in an urban agglomeration takes place either in an incumbent's R\&D department or via spinoffs taking advantage of diverse tacit knowledge flows.

How can these findings guide economic policy? One thing is glaringly obvious: there is no such thing as a single policy that will meet the needs of all regions. Further, it seems plausible to assume that policymakers are primarily interested in employment growth, whereas the question of where it takes place - in new businesses or in incumbent businesses - is initially of minor importance. With regard to the overriding goal of employment growth, our three regional archetypes already perform the best. Apparently, each region takes advantage of its special location factors. If one believes that “if it ain't broke, don't fix it," there is not much, if any, need for new policy regarding these archetypes. However, policy can be employed to enormous benefit if it is used to create a good business environment and acts appropriately and expeditiously with regard to possible threats and undesirable developments. In this 
context, industrial districts are vulnerable because of their high concentration of niches relying on blue-collar production (highest score for Factor 3). As described in Section 2.1, this business structure is supportive of process improvements and marginal innovations, but it is also at risk of suddenly becoming obsolete if some major change or innovation occurs. Therefore, especially important to these areas are entities such as chambers of commerce and industry that foster mutual communication and inter-industry and inter-regional cooperation. This sort of social network will allow the flow of fresh knowledge and thus guards against the risk of ignorance of major developments. It is perhaps obvious to point out that these support services need to be run by local decision makers who are intimately familiar with the region and the needs of its inhabitants and can make decisions based on more than just "forms and formulas.”

In contrast, industrial agglomerations are quite likely to already have organizations such as chambers of commerce and industry that can provide various consulting services. This type of region is more in need of a policy aimed at improving or expanding the regional education infrastructure, i.e., universities and schools of applied science, but also vocational schools, in a way that it is tailored to the needs of the prevailing industry. This, in turn, assures the future supply of the skilled and highly skilled employees it needs (Factor 2). This seems necessary, as industrial agglomerations are the only regions in which an increase in concentration is supportive of employment growth. Furthermore, cluster platforms supported by local politicians may foster quality and integration along the regional supply chain (Factor 4). As described in Section 2.2, this is especially important to prevent a strictly hierarchical market structure where suppliers are solely dependent on the large "hub” firm.

Urban agglomerations are primarily characterized by openness and diversity that is reflected in a diverse business environment (Factor 4) supportive of the creation of and competition for new ideas. However, this does not mean that the archetype of an urban agglomeration is 
packed with highly creative employees all working in the service sector. In fact, our analyses reveals that service-dependent cities such as Frankfurt and Hamburg are doing well but that Munich, which attracts both service companies and the R\&D-intensive parts of internationally successful manufacturers, does better. This leads us to the conclusion that even in the muchlauded age of services, the importance of the manufacturing industry must not be underestimated. This seems especially true for countries such as Germany that have historically enjoyed an extraordinarily successful manufacturing sector. Our policy recommendation for this type of region has two parts. On the one hand, urban agglomerations need a proper integration policy to offset the potential side effects of their openness, as well as some kind of amenity management, which will create an environment conducive to attracting and keeping high-potentials. On the other hand, urban agglomerations should not ignore manufacturing industries; a sufficient number of well-appointed industrial parks could be essential to further, and diversified, growth.

Regarding those regions that did not easily fit within a regional archetype, one can ascribe their lower performance to a less distinct manufacturing sector. As discussed earlier, Germany has an advantage in manufacturing that leads to a positive effect of Factor 3 on employment growth for all regional types. In comparison to industrial districts, our group of rural regions (Rest) has a small manufacturing sector and therefore lower employment growth; the group labeled Tendency to UA has a smaller manufacturing sector than the archetype urban agglomerations, which, again, leads to lower employment growth. Apparently, the former lack specialized small- and medium-sized firms while the latter are in need of attracting R\&D-intensive headquarters of global players. Finally, regions in the group labeled Between IA and UA already possess a developed manufacturing sector, but are lacking in innovation. Here, an increase of established firms’ R\&D departments could be crucial for employment growth. Regarding policy implications for these less easily classifiable regions, we oppose all direct interventions aiming at the artificial creation of one of the regional archetypes. Blindly 
following a "pattern” to create an archetype will most likely misjudge underlying complex structures in these regions and thus create the risk of causing undesired side-effects. We understand regional development as an evolutionary process: policymakers can work to create a supportive environment with pronounced Marshallian factors, but they cannot control the process itself. 


\section{References}

Acs, Z., Audretsch, D., Braunerhjelm, P., Carlsson, B. (2004) The Missing Link: The Knowledge Filter and Entrepreneurship in Endogenous Growth. Discussion Paper 4783, Center Economic and Policy Research.

Amin, A., Thrift, N. (1992) Neo-Marshallian Nodes in Global Networks, International Journal of Urban and Regional Research, 16: 571-587.

Audretsch, D. (1995) Innovation and Industry evolution. Cambridge, MA: MIT Press.

Audretsch, D., Keilbach, M. (2004) Entrepreneurship Capital and Economic Performance, Regional Studies, 38: 949-959.

Bade, F.-J., Laaser, C.-F., Soltwedel, R. (2003) Urban specialization in the internet ageempirical findings for Germany. Working Paper 1215, The Kiel Institute of World Economics.

Baumol, W. (2002) The Free-Market Innovation Machine. Princeton/Oxford: Princeton University Press.

Becattini, G. (1979) Dal Settore Industriale al Distreto Industriale. Alcune consideración sull’unitá di indagine dell economía industriale, Revista di Economia e Politica Industriale, 1: 1-8.

Becattini, G. (1990) The Marshallian Industrial District as a Socio-Economic Notion, in: Pyke, F., Becattini, G., Sengenberger, W. (1990) Industrial Districts and Inter-Firm Cooperation in Italy. Geneva: International Institute for Labour Studies: 37-51.

Becker, G. (1975) Human Capital: A Theoretical and Empirical Analysis with Special Reference to Education. New York, NY: Columbia University Press.

Best, M. (1990) The New Competition: Institutions of Industrial Restructuring. Cambridge, MA: Harvard University Press.

Bianchi, P. (1993) Innovation Policy at the Local and National Levels: The Case of EmiliaRomagna, European Planning Studies, 1: 25-41.

Callois, J.M., Aubert, F. (2007) Towards indicators of social capital for regional development issues, Regional Studies, 41.

Cooke, P. (1996) The New Wave of Regional Innovation Networks: Analysis, Characteristics and Strategy, Small Business Economics, 8: 159-171.

Costello, A.B., Osborne, J. (2005) Best practices in exploratory factor analysis: four recommendations for getting the most from your analysis, Practical Assessment Research \& Evaluation, 10: 1-9.

Duranton, G., Puga, D. (2001) Nursery cities: Urban diversity, process innovation, and the life cycle of products, American Economic Review, 91: 1454-1477.

Duranton, G., Puga, D. (2005) From sectoral to functional urban specialisation, Journal of Urban Economics, 57: 343-370.

Ellickson, R. (1991) Order Without Law. Cambridge, MA: Harvard University Press. 
Fabrigar, L.R., Wegner, D.T., MacCallum, R.C., Strahan, E.J. (1999) Evaluating the use of exploratory factor analysis in psychological research, Psychological Methods, 4: 272299.

Falck, O., Heblich, S. (2008) Modern Location Factors in Dynamic Regions, European Planning studies, forthcoming.

Feldman, M.P. (1999) The New Economics of Innovation, Spillovers and Agglomeration: A Review of Empirical Studies, Economics of Innovation and New Technology, 8: 5-25.

Florida, R. (2002a) The Rise of the Creative Class. New York, NY: Basic Books.

Florida, R. (2002b) Bohemia and Economic Geography, Journal of Economic Geography, 2: 55-71.

Fritsch, M. (2004) Entrepreneurship, Entry and Performance of New Businesses Compared in Two Growth Regimes: East and West Germany, Journal of Evolutionary Economics, 14: 525-542.

Fritsch, M., Brixy, U. (2004) The Establishment File of the German Social Insurance Statistics, Schmollers Jahrbuch/Journal of Applied Social Science Studies, 124: 183190.

Glaeser, E., Kolko, J., Saiz, A. (2001) Consumer City, Journal of Economic Geography, 1: 27-50.

Granovetter, M. (1973) The Strength of Weak Ties, American Journal of Sociology, 78: 13601380.

Greene, W. (2002) Econometric Analysis. $5^{\text {th }}$ ed., Upper Saddle River, NJ: Prentice Hall.

Greif, S., Schmiedl, D. (2002) Patentatlas Deutschland - Dynamik und Struktur der Erfindertätigkeit. Munich: Deutsches Patent- und Markenamt.

Griliches, Z. (1992) Patent Statistics as Economic Indicator: A Survey, Journal of Economic Literature, 28: 1661-1707.

Harrigan, K. (1985) Strategies for Joint Ventures. Lexington, MA: Lexington Books.

Jacobs, J. (1969) The Economy of Cities. New York, NY: Random House.

Jaffe, A., Trajtenberg, M., Henderson, R. (1993) Geographic Localization of Knowledge Spillovers as Evidenced by Patent Citations, Quarterly Journal of Economics, 63: 577598.

Krugman, P. (1991) Geography and Trade. Cambridge, MA: MIT Press.

Lee, S., Florida, R., Acs, Z. (2004) Creativity and Entrepreneurship: A Regional Analysis of New Firm Formation, Regional Studies, 38: 879-891.

Lundvall, B.-Å., Johnson, B. (1994) The learning economy, Journal of Industry Studies, 1: 23-42.

Maretzke, S. (2005) Aktualisierung des Infrastrukturindikators für die Neuabgrenzung der Fördergebiete der Gemeinschaftsaufgabe "Verbesserung der regionalen Wirtschaftsstruktur”, Bonn: Bundesamtes für Bauwesen und Raumordnung. 
Markusen, A. (1996) Sticky Places in Slippery Space: A Typology of Industrial Districts, Economic Geography, 72: 293-313.

Marshall, A. (1890) Principles of Economics. London: Macmillan.

Staber, U., Morrison, C. (2000) The Empirical Foundations of Industrial District Theory, in: Holbrook, J.A., Wolfe, D. (eds) Innovation, Institutions and Territory: Regional Innovation Systems in Canada. Montreal/Kingston: McGill-Queens Press: 19-41.

Nelson, R., Winter, S. (1982) An Evolutionary Theory of Economic Change. Cambridge, MA: Harvard University Press.

Pietrobelli, C. (2000) Competitiveness and its Socio-Economic Foundations: Empirical Evidence on the Italian Industrial Districts, in: Bagella, M., Becchetti, L. (eds) The Competitive Advantage of Industrial Districts - Theoretical and Empirical Analysis. Heidelberg, New York, NY: Physica-Verlag: 3-20.

Pigou, A.C. (1956) Memorials of Alfred Marshall. New York, NY: Kelly \& Millman Inc.

Piore, M., Sabel, C. (1984) The Second Industrial Divide. Possibilities for Prosperity. New York, NY: Basic Books Inc.

Porter, M. (1990) The Competitive Advantage of Nations, London: McMillan.

Putnam, R. (2000) Bowling Alone: The Collapse and Revival of American Community. New York: Simon and Schuster.

Polanyi, M. (1966) The Tacit Dimension. London: Routledge \& Kegan Paul.

Robbins, L. (1971) Autobiography of an Economist. London: Macmillan \& Co.

Romer, P. (1986) Increasing Returns and Long-run Growth, Journal of Political Economy, 94: 1002-1037.

Romer, P. (1990) Endogenous Technological Change, Journal of Political Economy, 98: 71102.

Sabel, C. (2002) 'Diversity, Not Specialization: The Ties That Bind the (New) Industrial District', in Curzio, A., Fortis, M. (eds) Complexity and Industrial Clusters: Dynamics and Models in Theory and Practice. New York, NY: Physica-Verlag: 107-22.

Schumpeter, J. (1941) Alfred Marshall's Principles: A Semi-Centennial Appraisal, American Economic Review, 31: 236-248.

Sinn, H.-W. (2007) Can Germany be Saved? The Malaise of the World's First Welfare State. Boston, MA: MIT Press.

Storper, M. (1993) Regional ,Worlds' of Production: Learning and Innovation in the Technology Districts of France, Italy and the USA, Regional Studies, 27: 433-455.

Tabachnick, B.G., Fidell, L.S. (2001). Using Multivariate Statistics. Boston, MA: Allyn and Bacon.

Womack, J., Jones, D., Roos, D. (1990) The Machine that Changed the World: The Story of Lean Production. New York, NY: Rawson and Associates. 


\section{CESifo Working Paper Series}

for full list see www.cesifo-group.org/wp

(address: Poschingerstr. 5, 81679 Munich, Germany, office@cesifo.de)

2028 Jarko Fidrmuc, Neil Foster and Johann Scharler, Labour Market Rigidities, Financial Integration and International Risk Sharing in the OECD, June 2007

2029 Bernardina Algieri and Thierry Bracke, Patterns of Current Account Adjustment Insights from Past Experience, June 2007

2030 Robert Dur and Hein Roelfsema, Social Exchange and Common Agency in Organizations, June 2007

2031 Alexander Libman and Lars P. Feld, Strategic Tax Collection and Fiscal Decentralisation: The Case of Russia, June 2007

2032 Øystein Foros, Hans Jarle Kind and Greg Shaffer, Resale Price Maintenance and Restrictions on Dominant Firm and Industry-Wide Adoption, June 2007

2033 Jan K. Brueckner and Kurt Van Dender, Atomistic Congestion Tolls at Concentrated Airports? Seeking a Unified View in the Internalization Debate, June 2007

2034 Viet Do and Ngo Van Long, International Outsourcing under Monopolistic Competition: Winners and Losers, June 2007

2035 Nadia Fiorino and Roberto Ricciuti, Determinants of Direct Democracy, June 2007

2036 Burkhard Heer and Alfred Maussner, Inflation and Output Dynamics in a Model with Labor Market Search and Capital Accumulation, June 2007

2037 Konstantinos Angelopoulos, Jim Malley and Apostolis Philippopoulos, Public Education Expenditure, Growth and Welfare, June 2007

2038 Maarten Bosker, Steven Brakman, Harry Garretsen and Marc Schramm, Adding Geography to the New Economic Geography, June 2007

2039 Steffen Henzel, Oliver Hülsewig, Eric Mayer and Timo Wollmershäuser, The Price Puzzle Revisited: Can the Cost Channel Explain a Rise in Inflation after a Monetary Policy Shock?, July 2007

2040 Rosario Crinò, Service Offshoring and White-Collar Employment, July 2007

2041 Carsten Hefeker and Michael Neugart, Labor Market Regulation and the Legal System, July 2007

2042 Bart Cockx and Muriel Dejemeppe, Is the Notification of Monitoring a Threat to the Unemployed? A Regression Discontinuity Approach, July 2007

2043 Alfons J. Weichenrieder, Profit Shifting in the EU: Evidence from Germany, July 2007 
2044 Annika Alexius and Bertil Holmlund, Monetary Policy and Swedish Unemployment Fluctuations, July 2007

2045 Axel Dreher, Jan-Egbert Sturm and Jakob de Haan, Does High Inflation Cause Central Bankers to Lose their Job? Evidence Based on a New Data Set, July 2007

2046 Guglielmo Maria Caporale and Luis A. Gil-Alana, Long Run and Cyclical Dynamics in the US Stock Market, July 2007

2047 Alessandro Balestrino, It is a Theft but not a Crime, July 2007

2048 Daniel Becker and Michael Rauscher, Fiscal Competition in Space and Time: An Endogenous-Growth Approach, July 2007

2049 Yannis M. Ioannides, Henry G. Overman, Esteban Rossi-Hansberg and Kurt Schmidheiny, The Effect of Information and Communication Technologies on Urban Structure, July 2007

2050 Hans-Werner Sinn, Please Bring me the New York Times - On the European Roots of Richard Abel Musgrave, July 2007

2051 Gunther Schnabl and Christian Danne, A Role Model for China? Exchange Rate Flexibility and Monetary Policy in Japan, July 2007

2052 Joseph Plasmans, Jorge Fornero and Tomasz Michalak, A Microfounded Sectoral Model for Open Economies, July 2007

2053 Vesa Kanniainen and Panu Poutvaara, Imperfect Transmission of Tacit Knowledge and other Barriers to Entrepreneurship, July 2007

2054 Marko Koethenbuerger, Federal Tax-Transfer Policy and Intergovernmental PreCommitment, July 2007

2055 Hendrik Jürges and Kerstin Schneider, What Can Go Wrong Will Go Wrong: Birthday Effects and Early Tracking in the German School System, July 2007

2056 Bahram Pesaran and M. Hashem Pesaran, Modelling Volatilities and Conditional Correlations in Futures Markets with a Multivariate t Distribution, July 2007

2057 Walter H. Fisher and Christian Keuschnigg, Pension Reform and Labor Market Incentives, July 2007

2058 Martin Altemeyer-Bartscher, Dirk T. G. Rübbelke and Eytan Sheshinski, Policies to Internalize Reciprocal International Spillovers, July 2007

2059 Kurt R. Brekke, Astrid L. Grasdal and Tor Helge Holmås, Regulation and Pricing of Pharmaceuticals: Reference Pricing or Price Cap Regulation?, July 2007

2060 Tigran Poghosyan and Jakob de Haan, Interest Rate Linkages in EMU Countries: A Rolling Threshold Vector Error-Correction Approach, July 2007 
2061 Robert Dur and Klaas Staal, Local Public Good Provision, Municipal Consolidation, and National Transfers, July 2007

2062 Helge Berger and Anika Holler, What Determines Fiscal Policy? Evidence from German States, July 2007

2063 Ernesto Reuben and Arno Riedl, Public Goods Provision and Sanctioning in Privileged Groups, July 2007

2064 Jan Hanousek, Dana Hajkova and Randall K. Filer, A Rise by Any Other Name? Sensitivity of Growth Regressions to Data Source, July 2007

2065 Yin-Wong Cheung and Xing Wang Qian, Hoarding of International Reserves: Mrs Machlup's Wardrobe and the Joneses, July 2007

2066 Sheilagh Ogilvie, 'Whatever Is, Is Right'?, Economic Institutions in Pre-Industrial Europe (Tawney Lecture 2006), August 2007

2067 Floriana Cerniglia and Laura Pagani, The European Union and the Member States: Which Level of Government Should Do what? An Empirical Analysis of Europeans' Preferences, August 2007

2068 Alessandro Balestrino and Cinzia Ciardi, Social Norms, Cognitive Dissonance and the Timing of Marriage, August 2007

2069 Massimo Bordignon, Exit and Voice. Yardstick versus Fiscal Competition across Governments, August 2007

2070 Emily Blanchard and Gerald Willmann, Political Stasis or Protectionist Rut? Policy Mechanisms for Trade Reform in a Democracy, August 2007

2071 Maarten Bosker and Harry Garretsen, Trade Costs, Market Access and Economic Geography: Why the Empirical Specification of Trade Costs Matters, August 2007

2072 Marco Runkel and Guttorm Schjelderup, The Choice of Apportionment Factors under Formula Apportionment, August 2007

2073 Jay Pil Choi, Tying in Two-Sided Markets with Multi-Homing, August 2007

2074 Marcella Nicolini, Institutions and Offshoring Decision, August 2007

2075 Rainer Niemann, The Impact of Tax Uncertainty on Irreversible Investment, August 2007

2076 Nikitas Konstantinidis, Gradualism and Uncertainty in International Union Formation, August 2007

2077 Maria Bas and Ivan Ledezma, Market Access and the Evolution of within Plant Productivity in Chile, August 2007 
2078 Friedrich Breyer and Stefan Hupfeld, On the Fairness of Early Retirement Provisions, August 2007

2079 Scott Alan Carson, Black and White Labor Market Outcomes in the $19^{\text {th }}$ Century American South, August 2007

2080 Christian Bauer, Paul De Grauwe and Stefan Reitz, Exchange Rates Dynamics in a Target Zone - A Heterogeneous Expectations Approach, August 2007

2081 Ana Rute Cardoso, Miguel Portela, Carla Sá and Fernando Alexandre, Demand for Higher Education Programs: The Impact of the Bologna Process, August 2007

2082 Christian Hopp and Axel Dreher, Do Differences in Institutional and Legal Environments Explain Cross-Country Variations in IPO Underpricing?, August 2007

2083 Hans-Werner Sinn, Pareto Optimality in the Extraction of Fossil Fuels and the Greenhouse Effect: A Note, August 2007

2084 Robert Fenge, Maximilian von Ehrlich and Matthias Wrede, Fiscal Competition, Convergence and Agglomeration, August 2007

2085 Volker Nitsch, Die Another Day: Duration in German Import Trade, August 2007

2086 Kam Ki Tang and Jie Zhang, Morbidity, Mortality, Health Expenditures and Annuitization, August 2007

2087 Hans-Werner Sinn, Public Policies against Global Warming, August 2007

2088 Arti Grover, International Outsourcing and the Supply Side Productivity Determinants, September 2007

2089 M. Alejandra Cattaneo and Stefan C. Wolter, Are the Elderly a Threat to Educational Expenditures?, September 2007

2090 Ted Bergstrom, Rod Garratt and Damien Sheehan-Connor, One Chance in a Million: Altruism and the Bone Marrow Registry, September 2007

2091 Geraldo Cerqueiro, Hans Degryse and Steven Ongena, Rules versus Discretion in Loan Rate Setting, September 2007

2092 Henrik Jacobsen Kleven, Claus Thustrup Kreiner and Emmanuel Saez, The Optimal Income Taxation of Couples as a Multi-Dimensional Screening Problem, September 2007

2093 Michael Rauber and Heinrich W. Ursprung, Life Cycle and Cohort Productivity in Economic Research: The Case of Germany, September 2007

2094 David B. Audretsch, Oliver Falck and Stephan Heblich, It’s All in Marshall: The Impact of External Economies on Regional Dynamics, September 2007 